\title{
MITOCHONDRIAL DNA DIVERSITY OF THE ALPINE NEWT (ICHTHYOSAURA ALPESTRIS) IN THE CARPATHIAN BASIN: EVIDENCE FOR MULTIPLE CRYPTIC LINEAGES ASSOCIATED WITH PLEISTOCENE REFUGIA*
}

\author{
Judit Vörös ${ }^{1}$, Zoltán Varga², IÑigo Martínez-Solano ${ }^{3}$, and Krisztián Szabó ${ }^{4}$ \\ ${ }^{1}$ Department of Zoology, Hungarian Natural History Museum \\ H-1088 Budapest, Baross u. 13, Hungary \\ E-mail: voros.judit@nhmus.hu; https://orcid.org/0000-0001-9790-1443 \\ ${ }^{2}$ Department of Evolutionary Zoology and Human Biology, University of Debrecen \\ H-4032 Debrecen, Egyetem tér 1., Hungary; E-mail: varga.zoltan@science.unideb.hu \\ ${ }^{3}$ Museo Nacional de Ciencias Naturales, CSIC, cl José Gutiérrez Abascal 2, 28006 Madrid, Spain, \\ E-mail: inigomsolano@gmail.com; https://orcid.org/0000-0002-2260-226X \\ ${ }^{4}$ Department of Ecology, University of Veterinary Medicine \\ H-1077 Budapest, Rottenbiller u. 50, Hungary, \\ E-mail: kr.szabo@gmail.com; https://orcid.org/0000-0002-5110-8279
}

The phylogeography and molecular taxonomy of the Alpine newt, Ichthyosaura alpestris, has been intensively studied in the past. However, previous studies did not include a comprehensive sampling from the Carpathian Basin, possibly a key region in the evolution of the species. We used a $1422 \mathrm{bp}$ long fragment of the mitochondrial genome to infer the species' evolutionary history in central-eastern Europe by assigning isolated Carpathian Basin populations from 6 regions to previously defined mtDNA lineages. We also revised the morphology-based intraspecific taxonomy of the species in the light of new genetic data. Alpine newt populations from the Carpathian Basin represented two different mitochondrial lineages. The Mátra, Bükk and Zemplén Mts populations can be assigned to the Western lineage of the nominotypical subspecies. Bakony and Örség populations showed high haplotype diversity and formed a separate clade within the Western lineage, suggesting that the Carpathian Basin might have provided cryptic refugia for Alpine newt populations in their cold-continental forest-steppe landscapes during the younger Pleistocene. Newts from Apuseni Mts were related to the Eastern lineage but formed a distinct clade within this lineage. Considering the morphological and genetic differentiation of the Bakony and Örség populations, consistent with a long independent evolutionary history, we propose these populations be referred to as Ichthyosaura alpestris bakonyiensis (Dely, 1964). We provide a redescription of this poorly known subspecies.

Keywords: Caudata, Salamandridae, phylogeography, molecular taxonomy, genetic diversity, Pleistocene refugia, alpine newt, Ichthyosaura alpestris.

\section{INTRODUCTION}

The Alpine newt (Ichthyosaura alpestris (Laurenti, 1768)) is widely distributed in the temperate and Mediterranean regions of Europe, showing exten-

* This paper is dedicated to the memory of our dear colleague, teacher and advisor, Dr. László Papp, taxonomist, dipterologist, who passed away recently. 
sive morphological and ecological variation (Recuero \& Martínez-Solano 2002, Roček et al. 2003, ANdreone \& Tripepi 2006, Sotiropoulos et al. 2008). Prior to the molecular era, the taxonomic status of certain populations, often isolated, was long debated. Moreover, several subspecies of doubtful validity were described based on morphology (body proportions and colouration) or life-history traits (e.g. Dely 1959, Herrero \& Arano 1986, Zuiderwijk 1997, Dubois \& Raffä̈lli 2009, SpeYbroeck et al. 2010, Lužnik et al. 2011, Speybroeck et al. 2020). With the advance of molecular technologies, multilocus datasets helped clarify the species' evolutionary history and phylogeography. Using mtDNA data, Sotiropoulos et al. (2007) defined five clades (A-E), divided into three highly divergent lineages (the Vlaşina lineage, restricted to a small area in the Balkans, a very diverse eastern lineage with samples from the rest of the Balkan Peninsula, and a more genetically homogenous western lineage including populations from South-western and Central Europe). These results were refined and partly confirmed by a time-calibrated multilocus phylogeny by $\mathrm{R}_{\mathrm{E}}$ CUERo et al. (2014). This study showed that the Vlaşina mtDNA lineage was not deeply divergent in nuclear DNA, and delineated four major lineages that are somewhat discordant with the taxonomical status of some formerly described subspecies (I. a. veluchiensis (Wolterstorff, 1935) in Greece, I. a. reiseri (Werner, 1902) and I. a. montenegrina (Radovanovic, 1951) in Eastern Europe and the Balkans, I. a. apuana (Bonaparte, 1839) + I. a. inexpectata (Dubois \& Breuil, 1983) on the Appenine Peninsula and I. a. alpestris + I. a. cyreni (Wolterstorff, 1932) in Western and Central Europe and northern Spain; Fig. 2A). The major events in the evolutionary history of the species according to this study were: 1) the split of Western and Eastern lineages in the late Miocene associated with Paratethys sea oscillations, 2) further parapatric diversifications due to local isolation events in higher temperature periods in the Miocene and Pliocene, and 3) distribution range shifts during the glacial cycles in the Pleistocene with local extinctions, recolonisation and secondary contact and admixture events.

While I. alpestris is very common in the surrounding Alps and Carpathians, its occurrence in the Carpathian Basin - an area defined by the Carpathians in the north, east and southeast, the Dinaric Alps from the southwest and the eastern Alpine domain in the West - is highly fragmented because of the lack of suitable habitats (they are restricted to the mountains at a minimum of $400 \mathrm{~m}$ elevation in that area). Some populations in the Carpathian Basin can be regarded as marginal in contrast with the continuously distributed Alpine and Carpathian populations (Őrség Region in the foothills of the Eastern Alps, Zemplén Mts in the Northern Mountain Range), while the remaining populations (Bakony Mts in Transdanubia, Mátra and Bükk Mts in the Northern Mountain Range and Apuseni Mts in Romania) represent geographical isolates (Figs $1 \& 3$ ). The fragmented occurrence of Alpine newts in this region has long intrigued taxonomists. 
Four subspecies of Ichthyosaura alpestris were described by Dely as that of Triturus alpestris (Dely 1959, 1964, 1967) based on populations from the Carpathian Basin. The descriptions were based on 26 morphometric and 24 osteological characters, which diagnosed Triturus alpestris bükkiensis in the Bükk Mts, T. a. satoriensis in the Zemplén Mts (both from the North Hungarian Mountains) (Dely 1959), T. a. carpathicus in the Southern Carpathians in Romania (Dely 1959), and T. a. bakonyiensis in the Bakony Mts in Transdanubia (Dely 1964). Several authors rejected the distinctiveness of three of the four subspecies (bükkiensis, satoriensis and carpathicus) on methodological grounds (RoČEK 1974, Denö̈l 1994, RAFFAËLli 2018). However, the status of T. a. bakonyiensis, described separately in 1964 in Dely's dissertation and then in 1967 in the book series Fauna Hungariae (only in Hungarian language), remains uncertain.

Since previous phylogeographic surveys (Sotiropoulos et al. 2007, RecueRo et al. 2014) did not include a comprehensive sampling of the Carpathian Basin, possibly a key region in the evolution of the species, our main goals in this study were (1) to describe the genetic diversity of Ichthyosaura alpestris in the Carpathian Basin based on mitochondrial data, (2) to infer the evolutionary history of the species in central-eastern Europe region by assigning isolated Carpathian Basin populations to previously defined mtDNA lineages, and (3) to revise the previously published morphology-based intraspecific taxonomy of the species in the light of new genetic data.

\section{MATERIAL AND METHODS}

Tissue samples were collected by tail clipping or swabbing from 24 living animals from 13 localities in 6 regions in the Carpathian Basin (Őrség Region and Bakony Mts in western Hungary, Mátra, Bükk and Zemplén Mts in the North Hungarian Mountains, and Apuseni Mts in Romania) during the breeding seasons of 2010-2012 (Fig. 1, Table 1). Tissue samples were preserved in $96 \%$ ethanol and kept at $-20^{\circ} \mathrm{C}$ until processing. Whole genomic DNA was extracted either using DNeasy Blood\&Tissue Kit (tails) or QIAmp DNA Mini Kit (swabs) extraction kits following the manufacturer's protocols (Qiagen, Hilden, Germany). Two mitochondrial gene regions were amplified by PCR: a 553 bp long partial sequence of the ribosomal 16s RNA gene (16S), using the primer pairs 16Sar-16Sbr (PALumbi et al. 1991) and a $689 \mathrm{bp}$ long fragment of the mitochondrial NADH dehydrogenase 4 gene (ND4), together with a $191 \mathrm{bp}$ fragment of the adjacent tRNAs (Ile, Leu, and partially Met) using the primer pairs ND4-Leu (ARÉvalo et al. 1994). PCRs were performed in a total volume of 50 $\mu \mathrm{l}$ using $1 \mathrm{U}$ of Taq polymerase (Thermo Fisher Scientific, Waltham, USA), $1.5 \mathrm{mM} \mathrm{MgCl}$, 10 pmol dNTPs (Thermo Fisher Scientific, Waltham, USA), 20 pmol of both primers and ca. $50 \mathrm{ng}$ of genomic DNA with the following profiles: $95^{\circ} \mathrm{C}$ for $2 \mathrm{~min}$, followed by 38 cycles of $95^{\circ} \mathrm{C}$ for $30 \mathrm{sec}, 50$ or $56^{\circ} \mathrm{C}$ for $60 \mathrm{sec}\left(16 \mathrm{~S}\right.$ and ND4, respectively) and $72^{\circ} \mathrm{C}$ for $60 \mathrm{sec}$, followed by a $7 \mathrm{~min}$ final extension at $72^{\circ} \mathrm{C}$. Amplified double-strand products were purified by using a High Pure PCR Product Purification Kit (Sigma-Aldrich, St. Louis, USA) and directly sequenced from both directions following the ABI Prism BigDye Terminator Cycle sequencing protocol on an ABI 3130 Genetic Analyser (Applied Biosystems, Foster City, USA). 
Sequences were collapsed into haplotypes using Collapse 1.2 (Posada 2011). These were aligned in CLUSTALW (ChenNA et al. 2003) using the default settings for gap opening and extension penalties followed by limited manual correction of gap placement. Sampled sequences were aligned and analysed together with previously published overlapping $I$. alpestris sequences from different lineages, covering the entire distribution range of the species (altogether 136 specimens, collapsed into 54 haplotypes; Recuero et al. 2014). ND4 sequences aligned perfectly, with no insertions or deletions. Due to alignment uncertainty in the tRNA sequences, only $1422 \mathrm{bp}$ of the dataset were used in the analyses.

In the Carpathian Basin samples, standard diversity indices (haplotype diversity and nucleotide diversity $\pi$ ) were calculated for the entire mtDNA dataset with DNASP 5.0 (Librado \& Rozas 2009). Relationships among mtDNA haplotypes in the Carpathian Basin were displayed by a median-joining network (BANDELT et al. 1999) using the software PopArt 1.7 (http://popart.otago.ac.nz.). The evolutionary divergence over sequence pairs between subspecies/evolutionary lineages was estimated using the software MEGA version 6. (TAmura et al. 2013). The analysis involved 147 nucleotide sequences. All positions with less than $95 \%$ site coverage were eliminated. That is, fewer than $5 \%$ alignment gaps, missing data, and ambiguous bases were allowed at any position. There were a total of 1422 positions in the final dataset.

Phylogenetic relationships were inferred by constructing Bayesian inference (BI) phylograms in MrBayes 3.1 (Ronquist \& Huelsenbeck 2003). Lissotriton vulgaris was selected as an outgroup (collected in Telkibánya, Zemplén Mts, Hungary; $48.45^{\circ} \mathrm{N}, 21.35^{\circ} \mathrm{E}$ ). The optimal partitioning strategy of the analysed dataset and the appropriate model of sequence evolution for each partition were estimated under the Bayesian Information Criterion (BIC) in the software Partition Finder 1.1 (Lanfear et al. 2012). Five independent partitions were defined as the best partitioning scheme: $H K Y+G$ for $16 S$ sequences, three separate models for the ND4 gene (K80 + I for 1st, TrN + I for 2nd, TrN+G for the 3rd codon positions) and K81uf $+\mathrm{G}$ for the tRNAs. MrBAyEs analyses consisted of two independent Metropolis-coupled Markov chain Monte Carlo runs, each with six incrementally heated

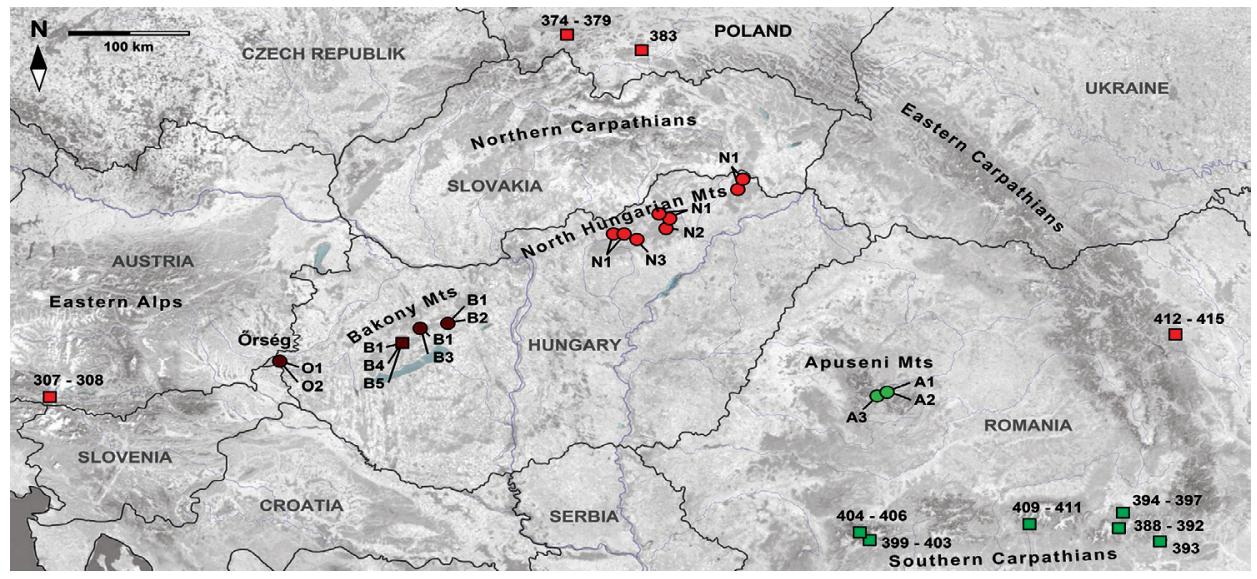

Fig. 1. Sampling sites and haplotypes found in and around the Carpathian Basin. Samples collected in this study are marked with circles and haplotype codes, and previously published samples are marked with squares and their codes as described in Recuero et al. (2014). Colours refer to different mtDNA lineages (see Figs 2 and 3) 
Table 1. MtDNA haplotypes found in sampled populations of I. alpestris in and around the Carpathian Basin, with GenBank accession numbers (16s and ND4), variable positions, number of polymorphic sites and diversity indices (mean and standard deviation of gene diversity $\mathrm{H}$, nucleotide diversity $\pi$, and $\Theta$ averaged for each population). Populations sampled by Recuero et al. (2014) are marked with an asterisk. Carp = Carpathians,

$\mathrm{NHM}=$ North Hungarian Mountains.

\begin{tabular}{|c|c|c|c|c|c|c|c|}
\hline Haplotype & $\begin{array}{c}\text { Apuse- } \\
\text { ni Mts }\end{array}$ & $\begin{array}{c}\text { Bakony } \\
\text { Mts }\end{array}$ & Őrség & NHM & $\begin{array}{l}{ }^{*} \mathrm{NW} \\
\text { Carp }\end{array}$ & $\begin{array}{c}{ }^{* S} \\
\text { Carp }\end{array}$ & Genbank accession no. \\
\hline IA_A1 & 1 & - & - & - & - & - & MW685537, MW685550 \\
\hline IA_A2 & 1 & - & - & - & - & - & MW685538, MW685551 \\
\hline IA_A3 & 1 & - & - & - & - & - & MW685539, MW685552 \\
\hline IA_B1 & - & 7 & - & - & - & - & MW685540, MW685553 \\
\hline IA_B2 & - & 3 & - & - & - & - & MW685541, MW685554 \\
\hline IA_B3 & - & 1 & - & - & - & - & MW685542, MW685555 \\
\hline IA_B4 & - & 2 & - & - & - & - & MW685543, MW685556 \\
\hline IA_B5 & - & 1 & - & - & - & - & MW685544, MW685557 \\
\hline IA_O1 & - & - & 2 & - & - & - & MW685545, MW685558 \\
\hline IA_O2 & - & - & 1 & - & - & - & MW685546, MW685559 \\
\hline IA_N1 & - & - & - & 7 & 10 & - & MW685547, MW685560 \\
\hline IA_N2 & - & - & - & 1 & - & - & MW685548, MW685561 \\
\hline IA_N3 & - & - & - & 1 & - & - & MW685549, MW685562 \\
\hline $\mathrm{N}$ & 3 & 14 & 3 & 9 & 10 & 20 & \\
\hline Hapl. num & 3 & 5 & 2 & 3 & 1 & 10 & \\
\hline Var. sites & 7 & 5 & 1 & 2 & 0 & 12 & \\
\hline $\mathrm{H}$ & $1(0.27)$ & $\begin{array}{l}0.72 \\
(0.1)\end{array}$ & $\begin{array}{c}0.67 \\
(0.31)\end{array}$ & $\begin{array}{c}0.41 \\
(0.19)\end{array}$ & 0 & $\begin{array}{c}0.82 \\
(0.08)\end{array}$ & \\
\hline$\pi \times 10^{-2}$ & $\begin{array}{c}0.32 \\
(0.00)\end{array}$ & $\begin{array}{l}0.074 \\
(0.02)\end{array}$ & $\begin{array}{c}0.05 \\
(0.02)\end{array}$ & $\begin{array}{l}0.031 \\
(0.02)\end{array}$ & 0 & $\begin{array}{c}0.15 \\
(0.02)\end{array}$ & \\
\hline$\Theta \times 10^{-2}$ & $\begin{array}{c}0.32 \\
(0.22)\end{array}$ & $\begin{array}{c}0.11 \\
(0.06)\end{array}$ & $\begin{array}{c}0.05 \\
(0.00)\end{array}$ & $\begin{array}{l}0.052 \\
(0.04)\end{array}$ & 0 & $\begin{array}{l}0.23 \\
(0.1)\end{array}$ & \\
\hline
\end{tabular}

Markov chains, run for 10 million generations and sampled every 1000 generations with the first $25 \%$ of samples excluded as burn-in. Convergence was assessed by examining the standard deviation of split frequencies, which was well below the recommended thresholds. A consensus phylogram was computed after discarding trees reconstructed during the default burn-in period.

\section{RESULTS}

Altogether 13 haplotypes were found in the 6 sampled localities of the Carpathian Basin (11 from our samples, two more from RECUERo et al. 2014; 


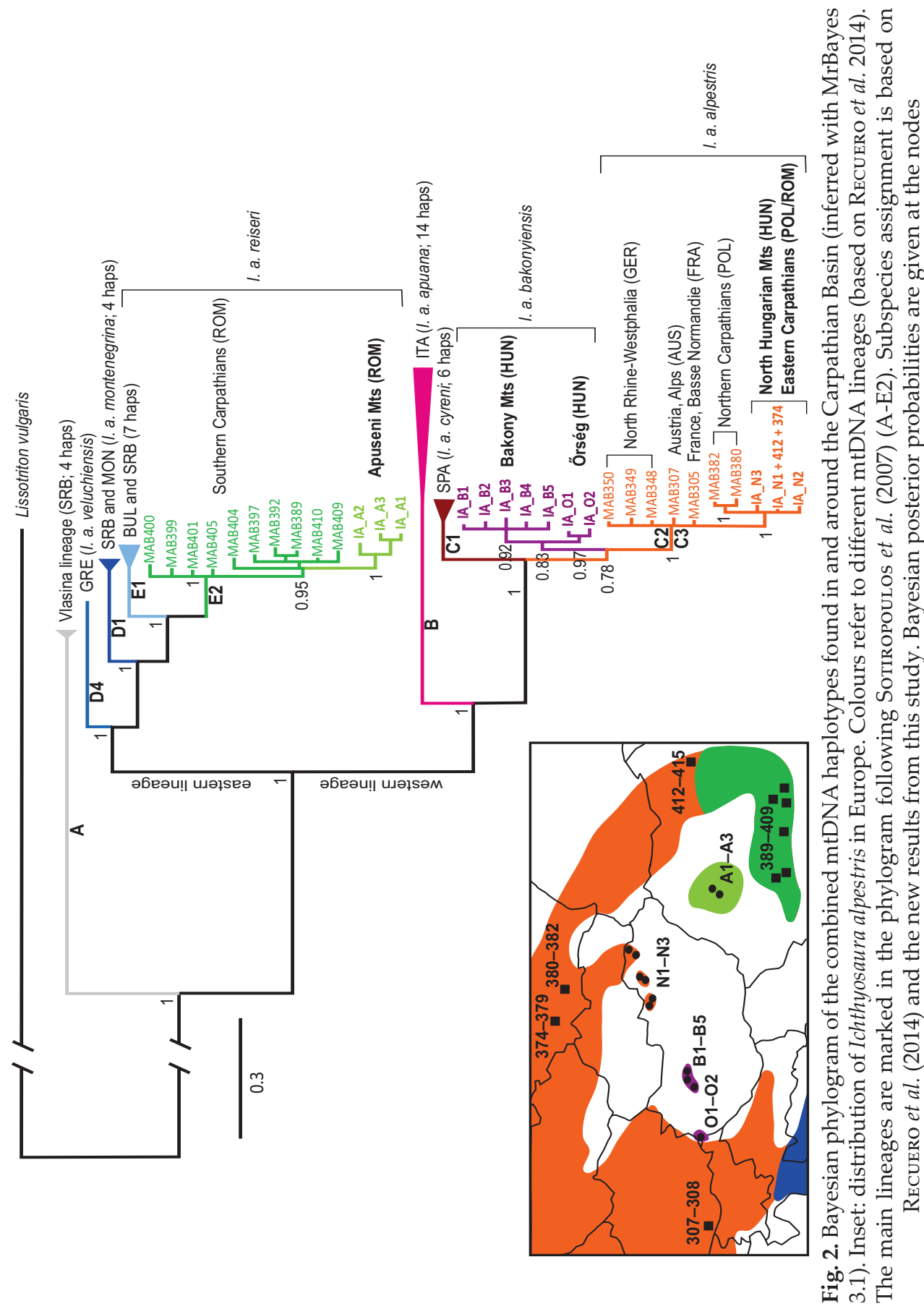


Table 2. Sampling locations, mtDNA haplotypes and geographic coordinates of the samples of I. alpestris analysed in this study. Samples marked with an asterisk were published by Recuero et al. (2014). RO = Romania, HU = Hungary

\begin{tabular}{|c|c|c|c|c|c|}
\hline Region, country & Locality & $\begin{array}{c}\text { Sample } \\
\text { name }\end{array}$ & $\begin{array}{l}\text { Haplo- } \\
\text { type }\end{array}$ & $\begin{array}{l}\text { Lati- } \\
\text { tude }\end{array}$ & $\begin{array}{l}\text { Lon- } \\
\text { gitude }\end{array}$ \\
\hline Apuseni Mts, RO & Vartop & IA_202 & IA_A1 & 46.51 & 22.66 \\
\hline Apuseni Mts, RO & Padis & IA_211 & IA_A2 & 46.59 & 22.71 \\
\hline Apuseni Mts, RO & Padis & IA_212 & IA_A3 & 46.59 & 22.71 \\
\hline Bakony Mts, HU & Isztimér & IA_401 & IA_B1 & 47.26 & 18.11 \\
\hline Bakony Mts, HU & Isztimér & IA_402 & IA_B2 & 47.26 & 18.11 \\
\hline Bakony Mts, HU & Isztimér & IA_403 & IA_B2 & 47.26 & 18.11 \\
\hline Bakony Mts, HU & Isztimér & IA_404 & IA_B2 & 47.26 & 18.11 \\
\hline Bakony Mts, HU & Bakonybél & IA_201 & IA_B1 & 47.26 & 17.67 \\
\hline Bakony Mts, HU & Bakonybél & IA_209 & IA_B1 & 47.26 & 17.67 \\
\hline Bakony Mts, HU & Bakonybél & IA_301 & IA_B3 & 47.26 & 17.67 \\
\hline Bakony Mts, HU & Bakonybél & IA_302 & IA_B1 & 47.26 & 17.67 \\
\hline Bakony Mts, HU & Bakonybél & IA_303 & IA_B1 & 47.26 & 17.67 \\
\hline Bakony Mts, HU & Ajka & MAB309* & IA_B4 & 47.04 & 17.65 \\
\hline Bakony Mts, HU & Ajka & MAB310* & IA_B1 & 47.04 & 17.65 \\
\hline Bakony Mts, HU & Ajka & MAB311* & IA_B1 & 47.04 & 17.65 \\
\hline Bakony Mts, HU & Ajka & MAB312* & IA_B5 & 47.04 & 17.65 \\
\hline Bakony Mts, HU & Ajka & MAB313* & IA_B4 & 47.04 & 17.65 \\
\hline Örség, HU & Szakonyfalu & IA_206 & IA_O1 & 46.91 & 16.23 \\
\hline Őrség, HU & Szakonyfalu & IA_207 & IA_O1 & 46.91 & 16.23 \\
\hline Őrség, HU & Szakonyfalu & IA_215 & IA_O2 & 46.91 & 16.23 \\
\hline NHM (Bükk Mts), HU & Kemesnye & IA_208 & IA_N2 & 48.13 & 20.50 \\
\hline NHM (Bükk Mts), HU & Bükkszentkereszt & IA_213 & IA_N1 & 48.07 & 20.59 \\
\hline NHM (Bükk Mts), HU & Répáshuta & IA_214 & IA_N1 & 48.04 & 20.55 \\
\hline NHM (Mátra Mts), HU & Parádsasvár & IA_001 & IA_N1 & 47.88 & 19.95 \\
\hline NHM (Mátra Mts), HU & Mátraszentimre & IA_002 & IA_N1 & 47.93 & 19.86 \\
\hline NHM (Mátra Mts), HU & Parád & IA_003 & IA_N3 & 47.88 & 20.05 \\
\hline NHM (Zemplén Mts), HU & Telkibánya & IA_217 & IA_N1 & 47.45 & 21.35 \\
\hline NHM (Zemplén Mts), HU & Telkibánya & IA_218 & IA_N1 & 47.45 & 21.35 \\
\hline NHM (Zemplén Mts), HU & Hollókő & IA_219 & IA_N1 & 48.56 & 21.40 \\
\hline
\end{tabular}


Fig. 1, Table 1). Newly found haplotype sequences were deposited in GenBank. Haplotype composition and diversity varied considerably among regions.

Populations in the western part of the Carpathian Basin proved to be highly polymorphic ( 2 haplotypes from 3 samples in the Örség and 5 haplotypes from 14 samples in the Bakony Mts), whereas samples from the North Hungarian Mountains had only three closely related haplotypes. However, two unique haplotypes were found in this region (N2 in the Bükk Mts and N3 in the Mátra Mts; Fig. 1). The Apuseni Mts population was highly diverse (3 haplotypes in 3 individuals, one of them differing by 6 substitutions from the other ones; Fig. 3). There were no shared haplotypes between geographic regions. For more detailed data on diversity indices, see Table 1. Genetic distances between subspecies/evolutionary lineages are shown in Table 3.

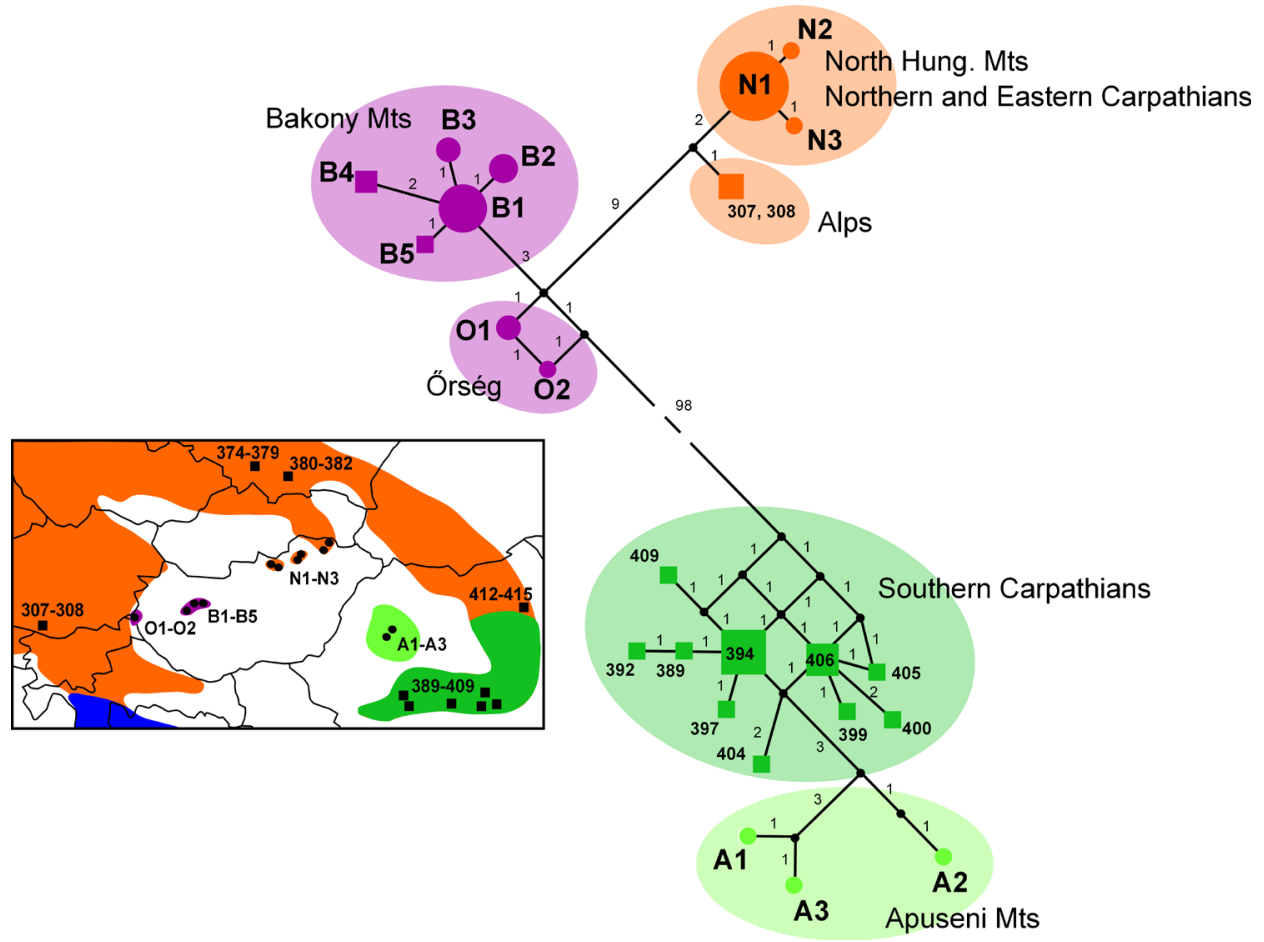

Fig. 3. Median-joining network of the combined mtDNA haplotypes found in and around the Carpathian Basin (drawn with PopArt 1.7). Inset: distribution of Ichthyosaura alpestris in this region. On the network, circles with haplotype names mark haplotypes found in this study, and squares with numbers mark haplotypes from Recuero et al. (2014). Nucleotide substitutions are marked with grey numbers. Colours refer to different mtDNA lineages (based on Recuero et al. 2014) 


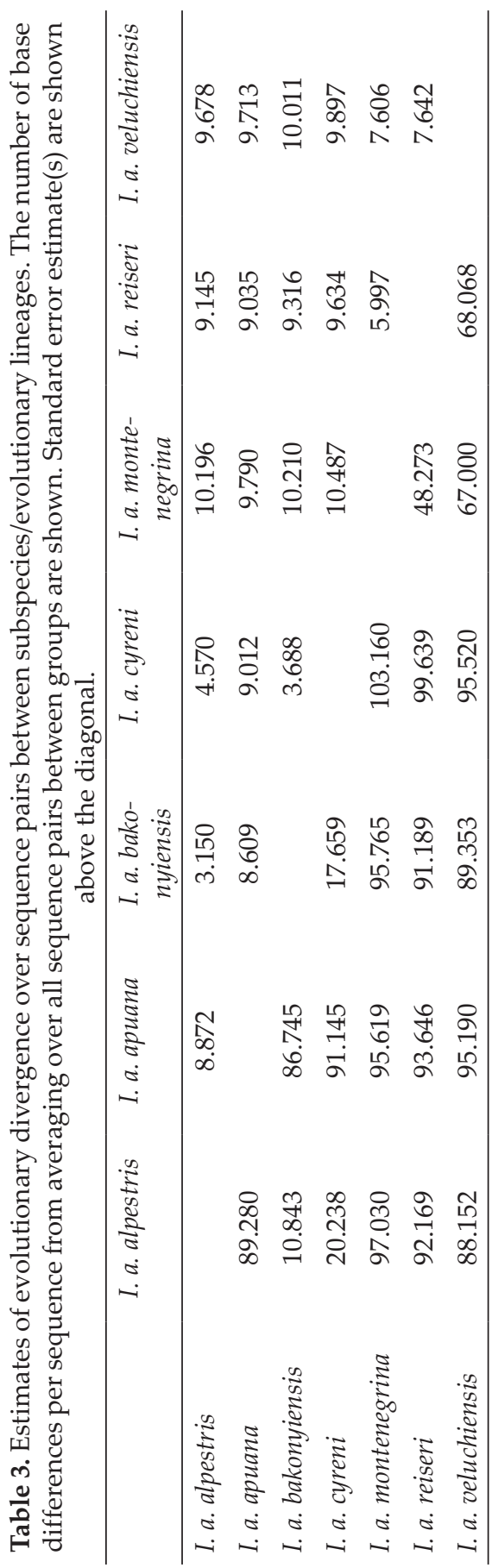

Despite their geographic proximity, Alpine newt populations in the Carpathian Basin represent two different mitochondrial lineages. The North Hungarian Mountain localities (Mátra, Bükk and Zemplén Mts) are very closely related to each other and can be assigned to the Western lineage (C3 mtDNA subclade both in Sotipoulos et al. 2007 and Recuero et al. 2014; Fig. 2), most of them bearing the same N1 haplotype as each individual found in the NE Carpathians (Poland and Romania; Fig. 3). Bakony and Őrség haplotypes formed a separated clade within the Western lineage $(\mathrm{C} 2-\mathrm{C} 3$ subclade; Fig. 2), differing by 11-18 substitutions from samples found in the Alps and the NE Carpathians (Fig. 3). Newts from Apuseni Mts are related to the Eastern lineage (E2 sublineage) but form a distinct clade within this lineage (Fig. 2), differing by 7-10 substitutions from the haplotypes found in the Southern Carpathians (Fig. 3). We found no evidence of admixture between the two main eastern and western lineages of the Alpine newt.

\section{DISCUSSION}

Due to its transitional biogeographical position, the Carpathian Basin is one of the regions with the highest biodiversity in Europe (WILLIAMs et al. 1999, VARGA 2010, 2019). While Pannonian, Illyrean, and Alpine influences overlap in the western and south-western parts of Transdanubia, Pannonian, Carpathian, and Dacian 
influences overlap in the north-eastern edges, and different Mediterranean elements (Holo and Ponto-Mediterranean, Balkan and Anatolian) enrich the Hungarian Middle Range's low elevation areas (VARgA 1995). The Alpine newt's evolutionary history in the Carpathian Basin is a testimony of this rich biogeographic history, with three different mitochondrial lineages meeting in this region and showing high levels of genetic diversity. Two lineages are associated with the major western lineage in Ichthyosaura alpestris: one in the Northern Hungarian Mountains and a second one in the Bakony Mts and Őrség area. Besides, a third lineage associated with the eastern lineage is present in the Apuseni Mts. This diversity mirrors patterns of genetic structure in numerous co-distributed taxa. For instance, an east-west genetic split has been documented in the Alpine and Carpathian lineages of Bombina variegata and Salamandra salamandra (Vörös et al. 2006, Vörös et al. 2016b), in Anguis fragilis and A. colchica inhabiting Transdanubia and the North Hungarian Mountains (SzAвó \& Vörös 2014), and in the Carpathian and Balkan clades of the adder, Vipera berus (Ursenbacher et al. 2006). Similar patterns of genetic differentiation have also been reported in some butterfly species in the Carpathian Basin. The genetic split, with or without admixture, between the south-western (Transdanubian) and north-eastern (sub)Carpathian populations has been observed e.g. in Parnassius mnemosyne (Pecsenye et al. 2015), Phengaris nausithous (Hollós et al. 2012) and Erebia medusa (Sснмiтt \& Seitz 2001). Recently, differentiation between the Örség region and Bakony Mts was also found in populations of the Marsh fritillary Euphydryas aurinia (PeCsenYe et al. 2018); both populations form a sub-clade within European populations, highly differentiated from the Transylvanian ones.

Recuero et al. (2014) hypothesised that the ancestor of Ichthyosaura alpestris was already widespread in the late Miocene. Oscillations of the Paratethys Sea level would have promoted the two major lineages' split during the Tortonian: the eastern lineage in the Balkans and the western lineage in the Alps. The Carpathian Basin might have been colonised by the two I. alpestris lineages along two major routes: the western lineage from the Alps to Transdanubia and from the Northeast Carpathians to the North Hungarian Mountains, and the eastern lineage would have colonised the Apuseni Mts from the Southern Carpathians.

Higher temperatures in Europe during the Miocene and Pliocene probably promoted the isolation of population groups into different mountain ranges, with the ranges of the different lineages further shifting during the Pleistocene glaciations. The Carpathian Basin might have provided cryptic refugia for Alpine newt populations in their cold-continental forest-steppe landscapes during the younger Pleistocene (Willis et al. 1997, Willis \& ANDEL 2004, VARGa 2010, Schmitt \& VARGa 2012), which is supported by the high haplotype diversity and the genetic differentiation of newts from the Bakony 
Mts and Örség area compared to the rest of the western lineage of $I$. a. alpestris. Using 35 loci Arano and Arntzen (1987) investigated the inter-populational genetic differentiation and evolutionary relationships within I. alpestris subspecies. They used four samples from Bakony Mts (Ajka) which nested within the I. alpestris alpestris clade of populations from France, Germany, Yugoslavia (that time), Austria and Bulgaria. Recuero et al. (2014) included five specimens from Bakony Mts in their comprehensive molecular study (locality Ajka, specimen IDs: MAB309-313). Their Bayesian consensus phylogram based on mtDNA data provided high statistical support for two main clades within I. a. alpestris, with the clade comprising samples from the Bakony Mts population being sister to a clade containing the rest of the nominotypical subspecies. The split of the two I. a. alpestris clades was estimated to occur in the Pleistocene, less than 1.6 Mya. The distinctiveness of this population was confirmed by the addition of new samples in our study.

The existence of cryptic refugia in the Carpathian Basin has been documented in several studies (see SchmitT \& VARGA 2012). In addition to the Alpine newt, three lineages of the Moor frog (Rana arvalis) (BАBIK et al. 2004), one lineage of the Adder, Vipera berus (Ursenbacher et al. 2006), and two lineages of the Danube crested newt, Triturus dobrogicus (VöRös et al. 2016a), may have survived the last glacial maximum in extra-Mediterranean, northerly refugia in the Carpathian Basin.

The split of the distinct clade of the Apuseni Mts is less than 2.5 Mya (when the E1 and E2 clades split). The Apuseni Mts is a detached lower range of the Southern Carpathians, spatially isolated from the main Carpathian Arc since the Tertiary (Mráz \& Ronikier 2016). This old divergence is associated with the high species and endemic richness of the region, making Apuseni Mts one of the major biodiversity hotspots in the Carpathians. The distinctiveness of the Apuseni Mts Ichthyosaura alpestris population underpins the importance of these mountains as a biogeographically distinct region with a high number of endemic taxa, including earthworms (Pop et al. 2010), aquatic insects (BÁLINT et al. 2011), and a distinct Salamandra salamandra lineage (VöRös et al. 2016b).

\section{Taxonomic implications}

In his dissertation, Dely (1964) presented a series of keys to identify all subspecies of Triturus alpestris (= Ichthyosaura alpestris) recognised at that time, including T. a. bakonyiensis. The key features include palatal teeth structure, head shape, snout shape, forelimb length, and overlap/no overlap of limbs when folded along the body. For comparison of T. a. bakonyiensis and T. a. alpestris (translated from DeLy 1964), see Table 4 and Figs 5-8. Altogether, he used 26 morphometrical and 24 osteological characters to compare the subspecies. 
Molnár (2001), in his PhD dissertation, surveyed Ichthyosaura alpestris populations from Hungary and used four diagnostic indices $(\mathrm{L} / \mathrm{LCd}, \mathrm{L} / \mathrm{Ltc}, \mathrm{L} /$ PA, L/Lie, where L = length of body, LCd = length of tail, Ltc = width of head, $\mathrm{PA}=$ length of forelimb, Lie = distance between fore and hind limb) introduced by RočEK (1974) to compare Hungarian I. alpestris samples with other populations and assess the morphometric similarity/differentiation concerning the nominotypical subspecies. This study provided evidence that Alpine newts from Örség and Bakony Mts significantly differ from the rest of the populations (L/Ltc and L/Lie for both males and females, and L/PA for males), while newts from Mátra, Bükk and Zemplén Mts were similar to I. a. alpestris. However, these results should be taken with caution because they are based on the comparison of measurements in live specimens with formalin-fixed ones.

Considering the levels of morphological differences found by DeLY (1964) and Molnár (2001) coupled with the genetic differentiation and the long independent evolutionary history of the Bakony + Örség clade, these populations may be referred to as Ichthyosaura alpestris bakonyiensis (Dely, 1964), and we call for additional studies on patterns of morphological and nuclear DNA variation in this taxon. In order to formally restitute Ichthyosaura alpestris bakonyiensis as a valid subspecies, below we provide the full description translated from DeLY (1964).

\section{Ichthyosaura alpestris bakonyiensis (Dely, 1964)}

(Figs 4-8)

Synonym: Triturus alpestris bakonyiensis Dely, 1964

Holotype: HNHM-HER-61.27.1., adult female, collected between 7-12 of May, 1961 by O. Gy. Dely. Type locality: Ajka-Felsőcsinger, Bocskor Hill, Bakony Mountains, Veszprém County, Hungary (Fig. 4).

Paratypes: one adult female (HNHM-HER-2002.45.2.) collected between 7-12 of May, 1961, and two adult males (HNHM-HER-2002.45.1., HNHM-HER-2002.45.3.) collected between 9-12. of May, 1961 by O. Gy. Dely. at the same location as the holotype.

Redescription and diagnosis: Body more or less short and robust. Total length is between 70.6-77.9 $\mathrm{mm}$ (mean $=73 \mathrm{~mm})$ (males) and 78.3-95.0 $\mathrm{mm}($ mean $=85.43 \mathrm{~mm})(\mathrm{fe}-$ males), body length is $41.5-46.3 \mathrm{~mm}$ (mean $=42 \mathrm{~mm}$ ) (males) and $46.2-56.3 \mathrm{~mm}$ (mean = $49.15 \mathrm{~mm}$ ) (females). Head robust and wide (especially at the corner of eyes) (Fig. 6). Snout longish, abruptly descending until the corner of mouth. Tip of snout is widely (males) or less widely (females) rounded until the outer edge of nares. Nares are positioned in the lateral corner of snout. Upper jaws form a semicircle from the nares running to the caudal direction and reach their widest point in the last third of the head, from where they continue slightly more narrow (males), or they diverge gradually until the caudal end of eyes where they reach the maximum width. From here, they continue nearly parallel (females). Lips are weakly developed. Palatal teeth start at the lower end of choanae, forming V-shape, with caudal ends slightly bending outward. 
Body is robust, limbs are short. When bending the forelimb forward, 1st finger stretches until between frontal end of eyes and nares, 2nd finger slightly outreaches tip of snout, while 3rd finger far outreaches tip of snout. When bending forelimb backwards and hindlimb forward along the body, 3rd finger of forelimb touches the tubercle of hindlimb. The length of the forelimb is 56.95-66.52\% (mean $=60.5 \%$ ) (males) and 48.46-63.08\% (mean $=55 \%$ ) (females) of the distance between forelimb and hindlimb.

Dorsal surface of males is greenish brown or greenish purple. The low mid-dorsal crest runs from the end of the head to the end of the tail, is yellow with black spots, and is 1-2 mm high. Body flank is ornated with a longitudinal band consisting of black spots with greyish-white margins. Below the band there is a bright blue stripe. Same stripe stretches on the sides of the head from the snout to the shoulders. Tail is a bit lighter or darker than body, with smaller black spots; ventral edge is yellow with black spots. Ventral surface is reddish orange, throat is light yellow with small grey spots. Limbs and cloaca are ornated with black spots.

Dorsal surface of females is greyish-green with reddish-brown marble pattern. A light stripe running from the end of the head to the end of the tail. The edge of the dorsal and ventral surfaces is densely covered with small black spots. Similar pattern is found between the tip of snout and the shoulders. Tail has the same colour as the dorsal surface of body, covered with marbled pattern and small black patches; ventral edge is yellow with
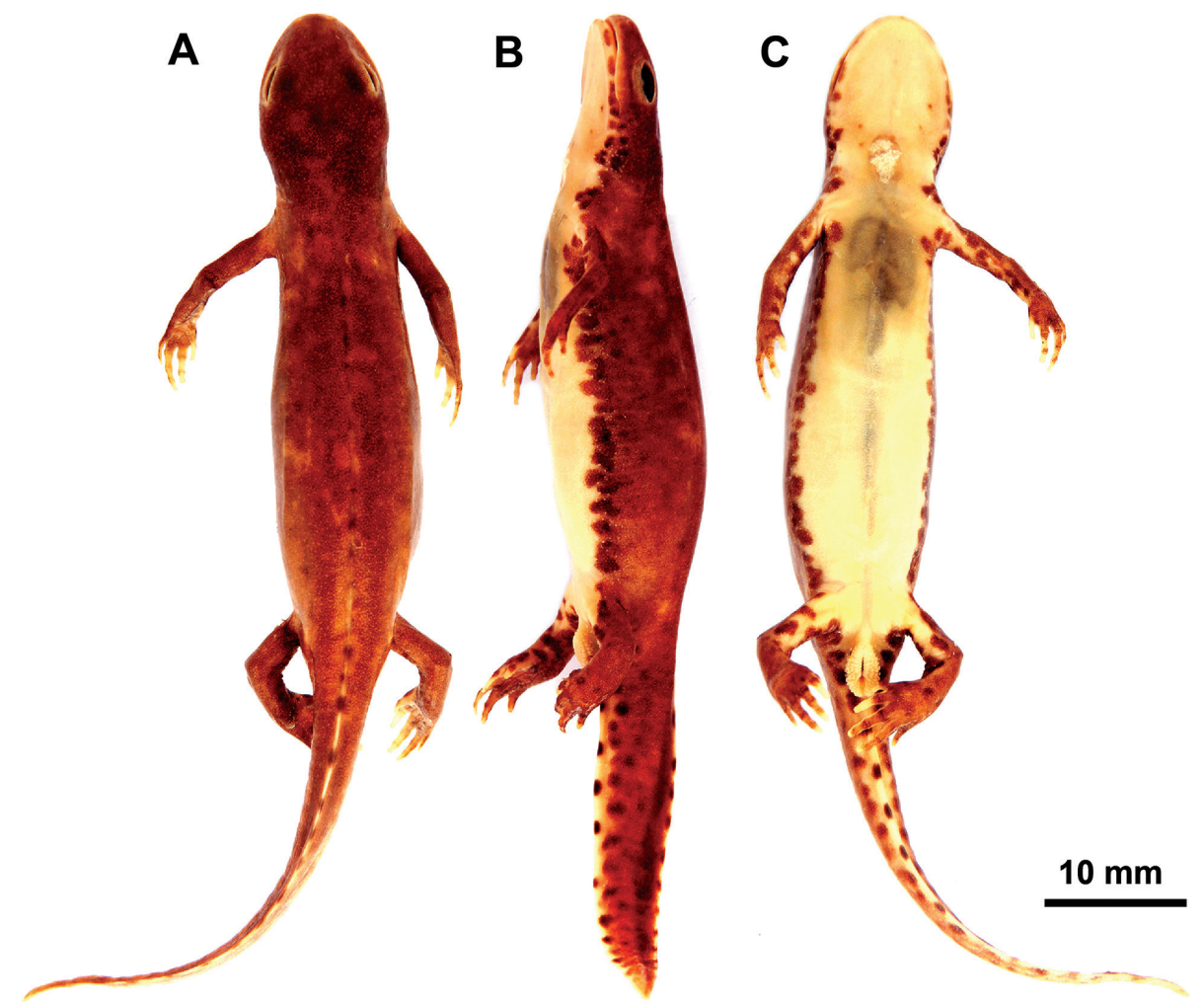

Fig. 4. Holotype of Triturus (=Ichthyosaura) alpestris bakonyiensis (Dely, 1964) (HNHMHER-61.27.1.) from dorsal (A), lateral (B) and ventral (C) view 
several small black dots above. Ventral surface is orange. Upper parts of limbs and fingers are with small black patches. Cloaca has the same colour as dorsal surface of the body.

Skull is medium size, slim and flat, sharply chopped in the middle. Length of skull is $9.2-9.3 \mathrm{~mm}$ (mean $=9.25 \mathrm{~mm}$ ) (males) and 9.8-10.6 $\mathrm{mm}$ (mean $=10.12 \mathrm{~mm}$ ) (females). Length of skull is $12.9-13.1 \%$ (mean $=13 \%)$ (males) and $11.2-12.5 \%$ (mean $=11,8 \%)(\mathrm{fe}$ males) of total body size. Width of skull is $57.6-62.3 \%$ (mean $=59.9 \%$ ) (males) and $61.2-66 \%$ $($ mean $=63.7 \%$ ) (females) of skull length. Width of quadratum is $76.0-78.4 \%$ (mean $=77.2 \%)$ (males) and $74-78.3 \%$ (mean $=77 \%$ ) (females) of the skull length. Snout more (males) or less (females) rounded, maxillarae form a semicircle running to caudal direction. Processus posteriores of the maxillarae are long, located close to the anterior ends of ptegygoideum, overreaching them and positioned a bit inwards compared to the quadratae. Cavum internasale do not reach upper edge of nares. Nasaliae are elongated (Fig. 8).

The index of regio otica compared to the condylobasal distance in anteroposterior direction is $29-29.3 \%$ (mean $=29.1 \%$ ) (males) and $27.3-30 \%$ (mean $=29.1 \%$ ) (females). The width index of regio otica is $103-111 \%$ (mean $=107 \%$ ) (males) and $103-124 \%$ (mean $=$ $111.5 \%$ ) (females). Buccal sacs are small and quadrangular. The anterosuperior ends of tympanica do not overlap with regio orbitale. Paraoccipital corners are moderate. The neu-

Table 4. Major keys to differentiate between I. a. alpestris (based on populations of Switzerland - Neuchatel and/or Germany - Harz Mts, Rosenthal, Hagenbach, Kassel, or Marburg) and I. a. bakonyiensis (based on populations of Bakony Mts - Ajka-Felsőcsinger, Németbánya, and/or Úrkút), translated from Hungarian, presented in Dely (1964).

\begin{tabular}{|c|c|c|}
\hline & I. alpestris alpestris & I. alpestris bakonyiensis \\
\hline $\begin{array}{l}\text { Palatal teeth struc- } \\
\text { ture }\end{array}$ & $\begin{array}{l}\text { Palatal teeth getting wider in } \\
\text { the last third (shape of a sugar } \\
\text { tong) and the caudal ends are } \\
\text { more or less bending inward. }\end{array}$ & $\begin{array}{l}\text { Palatal teeth V shaped, frontal } \\
\text { ends form sharp angle, caudal } \\
\text { ends are slightly bending } \\
\text { outward. }\end{array}$ \\
\hline Head shape & $\begin{array}{l}\text { Head longer than wide, oval } \\
\text { shape, never circular from } \\
\text { dorsal view. }\end{array}$ & $\begin{array}{c}\text { Head robust, approximately as } \\
\text { wide as the width of the body } \\
\text { at the axillary region. It reaches } \\
\text { its narrowest width behind the } \\
\text { eyes. }\end{array}$ \\
\hline Snout shape & $\begin{array}{l}\text { Snout long, tip of snout project- } \\
\text { ing forward or slightly broad- } \\
\text { ened (males). }\end{array}$ & $\begin{array}{l}\text { Snout longish, tip of snout is } \\
\text { widely (males) or less widely } \\
\text { (females) rounded until the } \\
\text { outer edge of nares. }\end{array}$ \\
\hline Forelimb length & $\begin{array}{l}\text { When bending the forelimb } \\
\text { forward, 1st finger outreach } \\
\text { frontal end of eyes, but never } \\
\text { reaches the nares, while } 2 \text { nd } \\
\text { finger reaches tip of snout. }\end{array}$ & $\begin{array}{l}\text { When bending the forelimb } \\
\text { forward, 1st finger stretches } \\
\text { until between frontal end of } \\
\text { eyes and nares, while } 2 \text { nd fin- } \\
\text { ger outreaches tip of snout. }\end{array}$ \\
\hline $\begin{array}{l}\text { Position of limbs } \\
\text { when folded along } \\
\text { the body }\end{array}$ & $\begin{array}{l}\text { When bending forelimb back- } \\
\text { wards and hindlimb forward } \\
\text { along the body, feet overlap } \\
\text { (males) or longest fingers just } \\
\text { or do not touch (females). }\end{array}$ & $\begin{array}{l}\text { When bending forelimb back- } \\
\text { wards and hindlimb forward } \\
\text { along the body, 3rd finger of } \\
\text { forelimb touches the tubercle } \\
\text { of hindlimb. }\end{array}$ \\
\hline
\end{tabular}



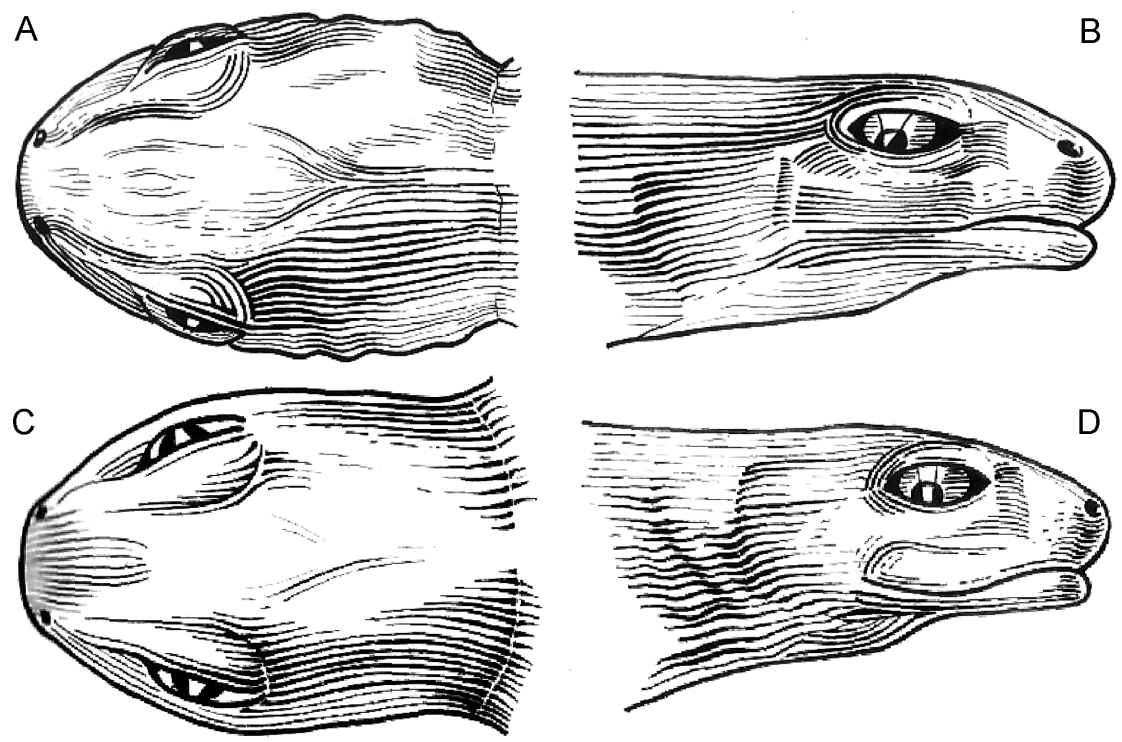

Fig. 5. Original drawings by O. Gy. Dely: male (A, B) and female (C, D) Ichthyosaura alpestris alpestris head shape from dorsal $(\mathrm{A}, \mathrm{C})$ and lateral $(\mathrm{B}, \mathrm{D})$ view

rocranium is $62.5-63.5 \%($ mean $=63 \%)($ males $)$ and $61.4-71.9 \%($ mean $=64.4 \%)($ females $)$ of the visceral cranium.

The intermaxillare reach the midline of vomero-palatine apparatus. Palatal teeth start at the inferior ends of choanae. From the starting point the two rows run apart caudal di-
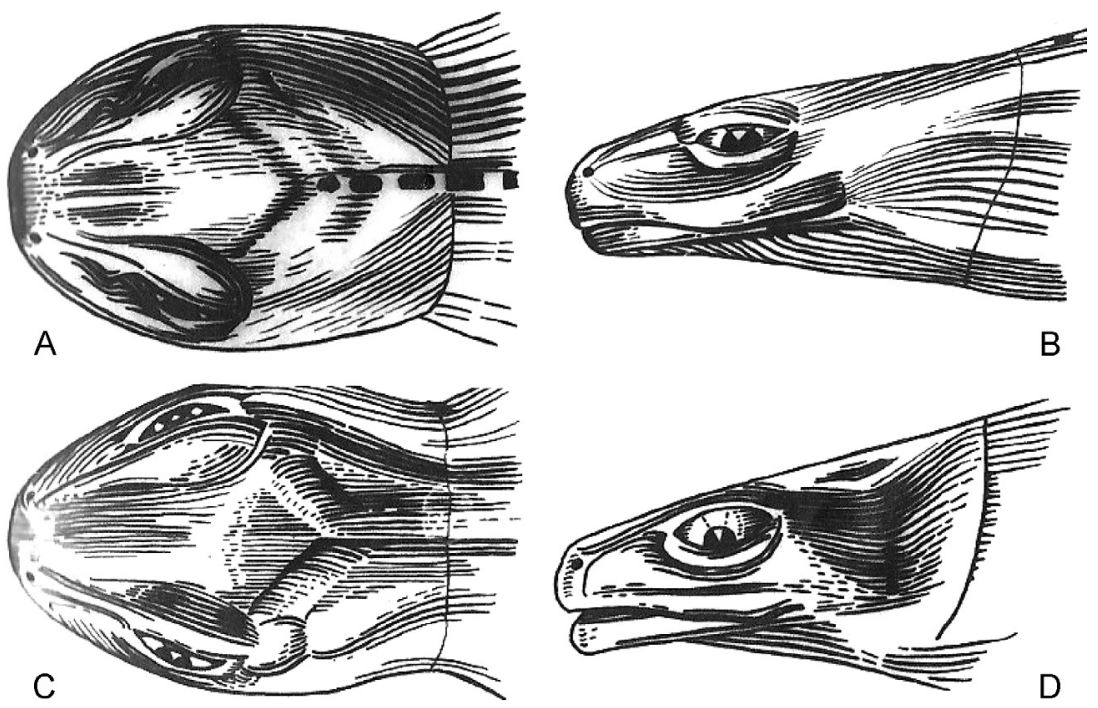

Fig. 6. Original drawings by O. Gy. Dely: male (A, B) and female (C, D) Ichthyosaura alpestris bakonyiensis head shape from dorsal $(\mathrm{A}, \mathrm{C})$ and lateral $(\mathrm{B}, \mathrm{D})$ view 

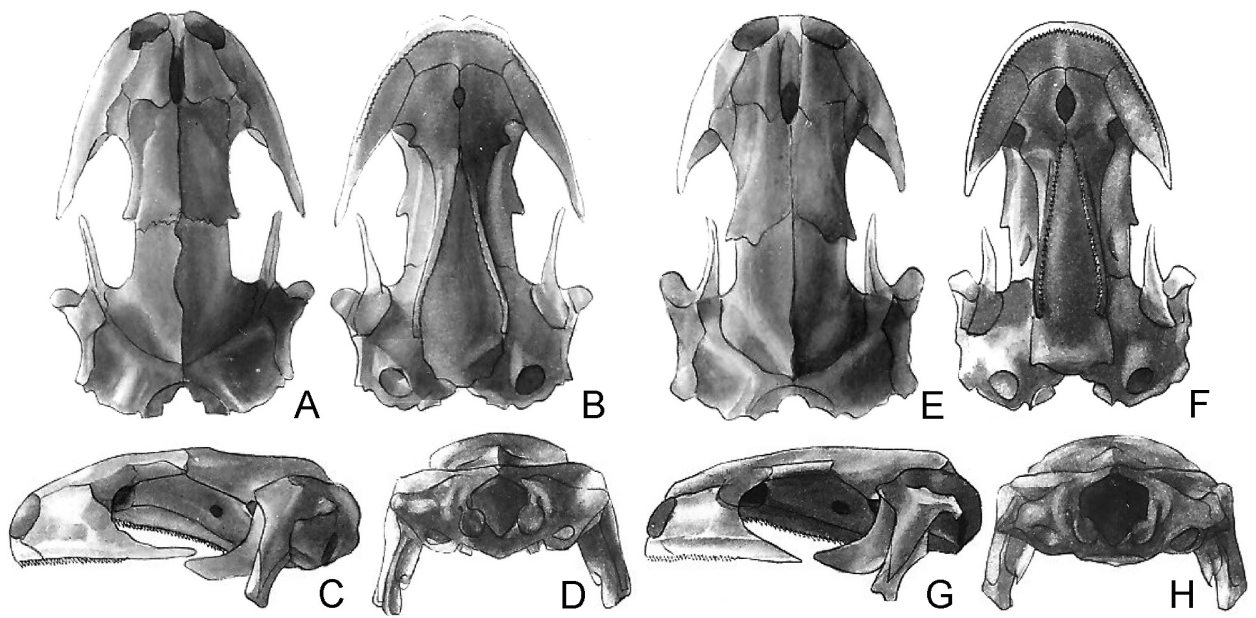

Fig. 7. Original drawings by O. Gy. Dely: female (A-D) and male (E-H) Ichthyosaura alpestris alpestris skull from dorsal $(A, E)$, ventral $(B, F)$, lateral $(C, G)$ and posterior $(D, H)$ view

rection and end far before the dorsal edge of the quadratum. The two rows of the V-shaped teeth are straight, caudal ends are slightly bending outward.

From lateral view the skull is flat. It starts inclined, and from the upper edge of the nostril it ascends until the caudal end of choanae; from here it runs straight until the arch above the foramen magnum; from here it abruptly (males) or gradually (females) descends until the upper edge of foramen magnum.

From posterior view the skull is flat and wide. The foramen magnum is quadrangular; the arch above is present mostly at males. Buccal sacs are depressed, canalis semicircularis is developed. The dorso-occipital line in lateral direction is either straight (males) or slightly cascading (females). Both fenestra ovalis are entirely visible (Fig. 8).
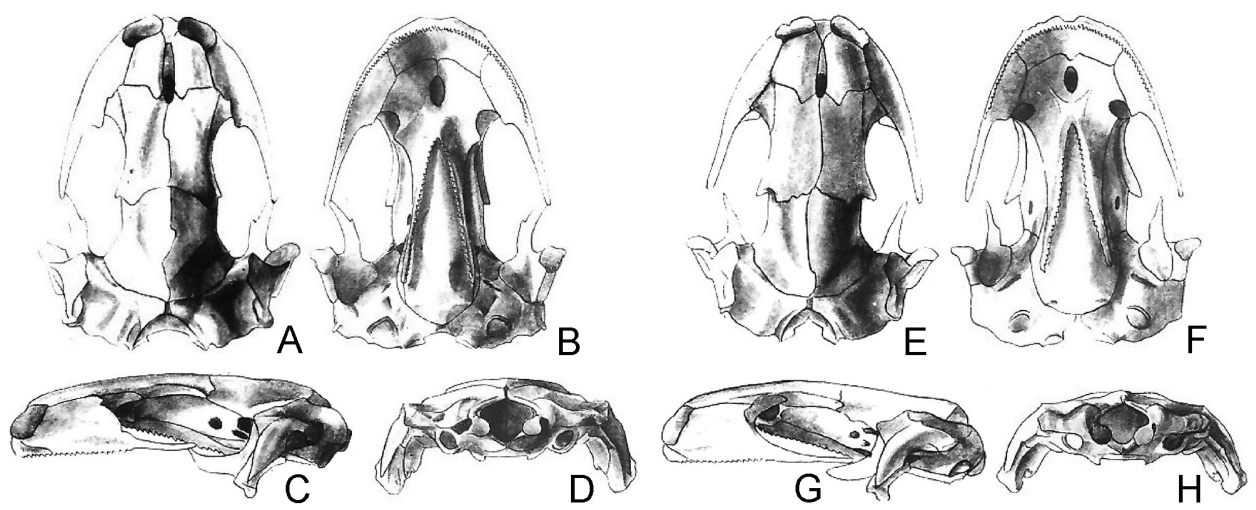

Fig. 8. Original drawings by O. Gy. Dely: female $(\mathrm{A}-\mathrm{D})$ and male $(\mathrm{E}-\mathrm{H})$ Ichthyosaura alpestris bakonyiensis skull from dorsal $(\mathrm{A}, \mathrm{E})$, ventral $(\mathrm{B}, \mathrm{F})$, lateral $(\mathrm{C}, \mathrm{G})$ and posterior $(\mathrm{D}, \mathrm{H})$ view 
Ichthyosaura alpestris bakonyiensis differs from I. a. alpestris in head shape, shape of vomero-palatinal teeth, shape and structure of skull, and some morphometric parameters such as full body length, tail length, forelimb length, length between tip of snout and gular fold, and distance between anterior corner of eye and forelimb (in males) or forelimb length and distance between anterior corner of eye and forelimb (in females).

Known range: Bakony Mountains and Őrség-Vendvidék Region, Hungary.

Protection status and threats: I. alpestris is strictly protected in Hungary (Decree 100/2012 (IX. 28.) VM). The most important threats to the species are destruction and desiccation of breeding sites, an increasing number of predators (e.g. wild boar; fish), improper wildlife management and use of forests, tourism, the spread of technical sports (Vörös et al. 2014) and infectious diseases such as chytridiomycosis (Vörös et al. 2018) or ranaviruses (Vörös et al. 2020).

Acknowledgements - We thank Mario García-París, Róbert Dankovics, Krisztián Harmos, Ádám Pongrácz and Sándor Bérces for their help with collecting tissue samples. We are grateful to Tamás Németh for helping with the photographs of the type-specimen. Collection permit was provided by the National Inspectorate for Environment, Nature and Water (14/3535/2/2010). The project was supported by the Hungarian Scientific Research Fund (OTKA K84071) to JV and ZV and the Bolyai János Research Scholarship of the Hungarian Academy of Sciences (BO/ 00579/14/8) to JV. Project no. [KH130360] has been implemented with the support provided from the National Research, Development and Innovation Fund of Hungary, financed under the [KH_18] funding scheme to JV.

We dedicate this publication to the memory of the brilliant taxonomist Dr. László Papp, head of Diptera Collection in the Hungarian Natural History Museum, who passed away on the 28th of March, 2021. He was not only a great scientist and an amazing person, he was an advisor for the first author of this paper, following and supporting her academic path. Moreover, as a lecturer of taxonomy he introduced this amazing science to hundreds of students including the first and last authors of this paper.

\section{REFERENCES}

Andreone, F. \& Tripepi, S. (2006): Triturus alpestris. Pp. 236-239. In: Sindaco, R., Doria, G., Razzetti, E. \& Bernini, F. (eds): Atlante degli Anfibi e dei Rettili d'ItalialAtlas of Italian Amphibians and Reptiles. - Societas Herpetologica Italica, Ed. Polistampa, Firenze.

Arano, B. \& Arntzen, J. W. (1987): Genetic differentiation in the alpine newt, Triturus alpestris. Pp. 21-24. In: van Gelder, J. J., Strijbosch, H. \& Bergers P. J. M. (eds): Proceedings of the Fourth Ordinary General Meeting of the Societas Europea Herpetologica. - Faculty of Sciences Nijmegen Press, Nijmegen.

Arévalo, E., Davis, S. K. \& Sites, J. W. (1994): Mitochondrial DNA sequence divergence and phylogenetic relationships among eight chromosome races of the Sceloporus grammicus complex (Phrynosomatidae) in central Mexico. - Systematic Biology 43: 387-418. https://doi.org/10.1093/sysbio/43.3.387 
Babik, W., Branicki, W., Sandera, M., Litvinchuk, S., Borkin, L. J., Irwin, J. T. \& Rafinski, J. (2004): Mitochondrial phylogeography of the moor frog, Rana arvalis. - Molecular Ecology 13: 1469-1480. https://doi.org.10.1111/j.1365-294X.2004.02157.x

BANdelt, H. J., Forster, P. \& RöHL, A. (1999): Median-joining networks for inferring intraspecific phylogenies. - Molecular Biology and Evolution 16: 37-48. https://doi. org/10.1093/oxfordjournals.molbev.a026036

Bálint, M., Ujvárosi, L., Theissinger, K., Lehrian, S., Mészáros, N. \& Pauls, S. U. (2011): The Carpathians as a major diversity hotspot in Europe. Pp 189-205. In: ZAchos, F. E. \& Habel, J. C. (eds): Biodiversity hotspots. - Springer, London. https://doi. org/10.1007/978-3-642-20992-5_11

Chenna, R., Sugawara, H., Koike, T., Lopez, R., Gibson, T. J., Higgins, D. G. \& Thompson, J. D. (2003): Multiple sequence alignment with the Clustal series of programs. - Nucleic Acids Research 31: 497-500. https://doi.org/10.1093/nar/gkg500

Dely, O. Gy. (1959): Examen du Triton alpestre (Triturus alpestris), spécialement en vue des populations de la Hongrie et des Carpathes. - Acta Zoologica Academiae Scientiarum Hungaricae 5: 255-315.

Dely, O. Gy. (1964): Környezettani és rendszertani vizsgálatok az alpesi götén. [Ecological and taxonomic investigations on the alpine newt.]. Dissertation for Candidate of Science degree, Budapest, $369 \mathrm{pp}$.

Dely, O. Gy. (1967): Kétéltúek-Amphibia, Magyarország Állatvilága. - Fauna Hungariae 20(3), Akadémia Kiadó, Budapest, 78 pp. [in Hungarian]

DenoËL, M. (1994): Le Triton alpestre, Triturus alpestris (Laurenti, 1768). - Les naturalistes Belges 75: 47-64.

Dubois, A. \& Raffä̈LLI, J. (2009): A new ergotaxonomy of the family Salamandridae Goldfuss, 1820 (Amphibia, Urodela). - Alytes 26: 1-85.

Herrero, P. \& Arano, B. (1986): Cytogenetic and morphological studies on Triturus alpestris cyreni. Pp. 151-154. In: RočEK, Z. (ed.): Studies in Herpetology. - Charles University Press, Praha.

Hollós, A., Pecsenye, K., Bereczki, J., Bátori, E., Rákosy, L. \& Varga, Z. (2012): Pattern of genetic and morphometric differentiation in Maculinea nausithous (Lepidoptera: Lycaenidae) in the Carpathian Basin. - Acta Zoologica Academiae Scientiarum Hungaricae 58: 87-103.

Lanfear, R., Calcott, B., Ho, S. Y. W. \& Guindon, S. (2012): PartitionFinder: combined selection of partitioning schemes and substitution models for phylogenetic analyses. Molecular Biology and Evolution 29: 1695-1701. https://doi.org/10.1093/molbev/mss020

Librado, P. \& Rozas, J. (2009): DnaSP v5: A software for comprehensive analysis of DNA polymorphism data. - Bioinformatics 25: 1451-1452. https://doi.org/10.1093/bioinformatics/btp187

LuŽNiK, M., KRYŠTufeK, B. \& BuŽAN, E. (2011): Mitochondrial sequences do not support the independent taxonomic position of the extinct Alpine newt subspecies Mesotriton alpestris lacusnigri. - Amphibia-Reptilia 32: 435-440. https://doi. org/10.1163/017353711X588191

Molnár, P. (2001): Alpesi gőte (Triturus alpestris Laurenti, 1768) populációk morfometriai és élőhelypreferencia vizsgálata hazai előfordulási területein. - MSc thesis, University of Debrecen, 50 pp. [in Hungarian]

Mráz, P. \& Ronikier, M. (2016): Biogeography of the Carpathians: evolutionary and spatial facets of biodiversity. - Biological Journal of the Linnean Society 119: 528-559. https:// doi.org/10.1111/bij.12918 
Palumbi, S. R., Martin, A. P., Romano, S. L., McMillan, W. O., Stice, L. \& Grabowski, G. (1991): The Simple Fool's Guide to PCR. - Department of Zoology, University of Hawaii, Honolulu, 24 pp.

Pecsenye, K., Tóth, J., Bereczki, J., Szolnoki, N. \& Varga, Z. (2015): Genetic structure of Parnassius mnemosyne (Lepidoptera: Papilionidae) populations in the Carpathian Basin. - Organisms, Diversity, Evolution 16: 809-819. https://doi.org/10.1007/s13127016-0281-7

Pecsenye, K., Tóth, A., Bereczki, J., Tóth, J. P., Katona, G. \& Varga, Z. (2018): Surprising diversity in the Pannonian populations of Marsh Fritillary (Euphydryas aurinia, Lepidoptera: Nymphalidae): Morphometric and molecular aspects. - Journal of Zoological Systematics and Evolutionary Research. https://doi.org/10.1111/jzs.12227

Pop, A. A., Pop, V. V. \& Csúzdi, Cs. (2010): Significance of the Apuseni Mountains (the Carpathians) in the origin and distribution of Central European earthworm fauna (Oligochaeta: Lumbricidae). - Zoology Middle East 51:89-110. https://doi.org/10.1080/ 09397140.2010 .10638462

Popart 1.7 [Online] (available at http://popart.otago.ac.nz.).

Posada, D. (2011): Collapse: Describing haplotypes from sequence alignments. [Online]. (Available at http://darwin.uvigo.es/software/collapse.html).

RAFfä̈LlI, J. (2018): Proposal for a new taxonomic arrangement of Ichthyosaura alpestris (Laurenti, 1768) (Urodela, Salamandridae), an iconic species with a complex phylogenetic structure. - Alytes 36: 178.

Recuero, E. \& Martinez-Solano, I. (2002): Triturus alpestris (Laurenti, 1768). Triton alpino. Pp. 58-60. In: Pleguezuelos, J. M., Marquez, R. \& Lizana, M. (eds): Atlas y libro rojo de los anfibios y reptiles de España. - Direccion General de Conservacion de la Naturaleza-Asociacion Herpetologica Española, Madrid.

Recuero, E., Buckley, D., García-París, M., Arntzen, J. W., Cogâlniceanu, D. \& MarTínez-Solano, I. (2014): Evolutionary history of Ichthyosaura alpestris (Caudata, Salamandridae) inferred from the combined analysis of nuclear and mitochondrial markers. - Molecular Phylogenetics and Evolution 81: 207-220. https://doi.org/10.1016/j. ympev.2014.09.014

RočEK, Z. (1974): Biometrical investigations of Central European populations of the Alpine newt, Triturus alpestris alpestris (Laurenti, 1768) (Amphibia: Urodela). - Acta Universitatis Carolinae, Biologica 5-6: 295-373.

Roček, Z., Joly, P. \& Grossenbacher, K. (2003): Triturus alpestris (Laurenti, 1768) - Bergmolch. Pp. 607-656. In: Grossenbacher, K. \& Tiesmeier, B. (eds): Handbuch der Reptilien und Amphibien Europas; Band 4/IIA Schwanzlurche (Urodela) IIA Salamandridae II: Triturus I. - Aula-Verlag, Wiebelsheim.

Ronquist, F. \& Huelsenbeck, J. P. (2003): MrBayes 3: Bayesian phylogenetic inference under mixed models. - Bioinformatics 19: 1572-1574. https://doi.org/10.1093/bioinformatics/btg180

Sснмiтt, T. \& Seitz, A. (2001): Intraspecific allozymatic differentiation reveals the glacial refugia and the postglacial expansions of European Erebia medusa (Lepidoptera: Nymphalidae). - Biological Journal of the Linnean Society 74: 429-458. https://doi. org/10.1006/bijl.2001.0584

Schmitt, T. \& VARGA, Z. (2012): Extra-Mediterranean refugia: The rule and not the exception? - Frontiers in Zoology 9: 22. https://frontiersinzoology.biomedcentral.com/articles/10.1186/1742-9994-9-22 
Sotiropoulos, K., Eleftherakos, K., Džukić, G., Kalezić, M. L., Legakis, A. \& Polymeni, R. M. (2007): Phylogeny and biogeography of the Alpine newt Mesotriton alpestris (Salamandridae, Caudata), inferred from mtDNA sequences. - Molecular Phylogenetics and Evolution 45: 211-226. https://doi.org/10.1016/j.ympev.2007.03.012

Sotiropoulos, K., Eleftherakos, K., Kalezić, M. L., Legakis, A. \& Polymeni, R. M. (2008): Genetic structure of the alpine newt, Mesotriton alpestris (Salamandridae, Caudata), in the southern limit of its distribution: Implications for conservation. - Biochemical Systematics and Ecology 36: 297-311. https://doi.org/10.1016/j.bse.2007.10.002

Speybroeck, J., Beukema, W. \& Crochet, P.-A. (2010): A tentative species list of the European herpetofauna (Amphibia and Reptilia) - an update. - Zootaxa 2492: 1-27. https:// doi.org/10.5281/zenodo.195659

Speybroeck, J., Beukema, W., Dufresnes, C., Fritz, U., Jablonski, D., Lymberakis, P., Martínez-Solano, I., Razzetti, E., Vamberger, M., Vences, M., Vörös, J. \& Crochet, P-A. (2020): Species list of the European herpetofauna - 2020 update by the Taxonomic Committee of the Societas Europaea Herpetologica. - Amphibia-Reptilia 41: 139-189. https://doi.org/10.1163/15685381-bja10010

Szabó, K. \& Vörös, J. (2014): Distribution and hybridisation of Anguis fragilis and A. colchica in Hungary. - Amphibia-Reptilia 35: 135-140. https://doi.org/10.1163/15685381-00002927

Tamura, K., Stecher, G., Peterson, D., Filipski, A., \& Kumar, S. (2013): MEGA6: Molecular Evolutionary Genetics Analysis version 6.0. - Molecular Biology and Evolution 30: 2725-2729. https://doi.org/10.1093/molbev/mst197

Ursenbacher, S., Carlsson, M., Helfer, V., Tegelstrom, H. \& Fumagalli, L. (2006): Phylogeography and Pleistocene refugia of the adder (Vipera berus) as inferred from mitochondrial DNA sequence data. - Molecular Ecology 15: 3425-3437. https://doi. org/10.1111/j.1365-294X.2006.03031.x

VARGA, Z. (1995): Geographical patterns of biodiversity in the Palearctic and in the Carpathian Basin. - Acta Zoologica Academiae Scientiarum Hungaricae 41: 71-92.

VARGA, Z. (2010): Extra-Mediterranean Refugia, Post-Glacial Vegetation History and Area Dynamics in Eastern Central Europe. Pp. 57-87. In: Habel J.C. \& Assmann T. (eds): Relict species: Phylogeography and conservation biology. - Springer-Verlag Berlin, Heidelberg. https://doi.org/10.1007/978-3-540-92160-8_3

VARGA, Z. (2019): Biogeográfia - az élet földrajza. [Biogeography - the geography of life.] Pars Kft., Nagykovácsi, 610 pp.

Vörös, J., Alcobendas, M., Martínez-Solano, I. \& García-París, M. (2006): Evolution of Bombina bombina and Bombina variegata (Anura: Discoglossidae) in the Carpathian Basin: a history of repeated mt-DNA introgression across species. - Molecular Phylogenetics and Evolution 38: 705-715. https://doi.org/10.1016/j.ympev.2005.08.010

Vörös, J., Herczeg, D., FülöP, A., GÁL, J. T., DÁN, Á., Harmos, K. \& BosCH, J. (2018): Batrachochytrium dendrobatidis in Hungary: a review of recent and historical occurrence. - Acta Herpetologica 13: 125-40. https://doi.org/10.13128/Acta_Herpetol-22611

Vörös, J., Herczeg, D., Papp, T., Monsalve-Carcano, C. \& Bosch, J. (2020): First detection of Ranavirus infection in Hungary: A survey of amphibians. - Herpetology Notes 13: 213-217.

Vörös, J., KIss, I. \& PuKY, M. (2014): Amphibian declines and conservation in Hungary. Pp. 99-130. In: Heatwole, H. \& Wilkinson, J. W. (eds): Status of decline of Amphibians: Eastern Hemisphere. Amphibian Biology Vol. 11. - Pelagic Publishing, Exeter.

Vörös, J., Mikulíček, P., Major, Á., Recuero, E. \& Arntzen, J. W. (2016a): Phylogeographic analysis reveals northerly refugia for the riverine amphibian Triturus dobrogicus 
(Caudata: Salamandridae). - Biological Journal of the Linnean Society 119: 974-991. https://doi.org/10.1111/bij.12866

Vörös, J., Ursenbacher, S., Kiss, I., Jelic, D., Schweiger, S. \& Szabó, K. (2016b): Increased genetic structuring of isolated Salamandra salamandra populations (Caudata: Salamandridae) at the margins of the Carpathian Mountains. - Journal of Zoological Systematics and Evolutionary Research 55: 138-149. https://doi.org/10.1111/jzs.12157

Williams, P., Humphries, C., \& Araújo, M. (1999): Mapping Europe's biodiversity. Pp. 12-20. In: Delbaere, B. (ed.): Facts and figures on Europe's biodiversity, state and trends 1998-1999. - ECNC, Tilburg.

Willis, K. J., Braun, M., Sümegi, P. \& Tóth, A. (1997): Does soil change cause vegetation change or vice versa? A temporal perspective from Hungary. - Ecology 78: 740-750. https://doi.org/10.1890/0012-9658(1997)078[0740:DSCCVC]2.0.CO;2

Willis, K. J. \& van Andel, T. H. (2004) Trees or no trees? The environments of Central and Eastern Europe during the last glaciation. - Quaternary Science Reviews 23: 2369-2387. https://doi.org/10.1016/j.quascirev.2004.06.002

Zuiderwijk, A. (1997): Triturus alpestris (Laurenti, 1768). Pp. 72-73. In: Gasc, J. P., Cabela, A., Crnobrnja-Isailović, J., Dolmen, D., Grossenbacher, K., Haffner, P., Lescure, J., Martens, H., Martínez Rica, J. P., Maurin, H., Oliveira, M. E., Sofianidou, T. S., Veith, M. \& Zuiderwijk, A. (eds): Atlas of amphibians and reptiles in Europe. - Societas Europaea Herpetologica, Muséum National d'Histoire Naturelle, Paris.

Received September 7, 2020, accepted March 18, 2021, published May 31, 2021 
